Tessa Azhari, Aldri Frinaldil Pengaruh Pengelolaan Pengaduan terhadap Kepuasan Peserta di PT. Taspen (Persero) Kantor Cabang Padang

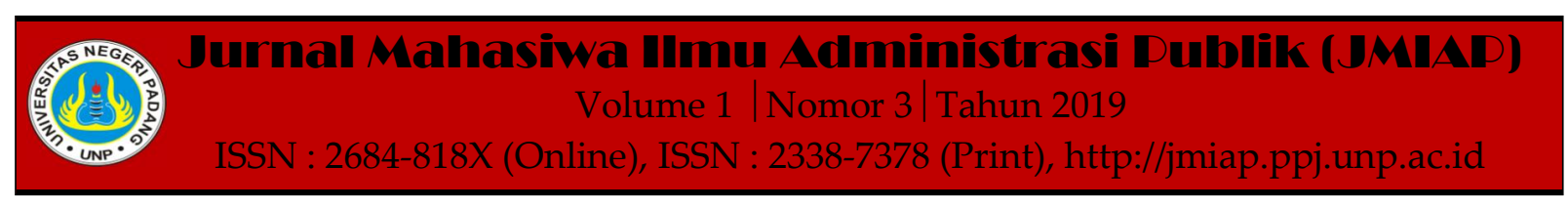

\title{
PENGARUH PENGELOLAAN PENGADUAN TERHADAP KEPUASAN PESERTA DI PT. TASPEN (PERSERO) KANTOR CABANG PADANG
}

\author{
Tessa Azhari $^{1(a)}$, Aldri Frinaldi ${ }^{2(b)}$ \\ ${ }^{1}$ Jurusan Ilmu Administrasi Negara, Universitas Negeri Padang \\ ${ }^{2}$ Jurusan Ilmu Administrasi Negara, Universitas Negeri Padang \\ a)tessaazhari93@gmail.com, ${ }^{b)}$ alfrinaldi@gmail.com
}

\begin{abstract}
This purpose of this study was to analyze complaint management for participant / customer satisfaction at PT. Taspen (Persero) Padang Office. This research is quantitative with associative methods. The background of this research is that there werw still complaints management that had not been optimal. This research was conducted at PT. Taspen (Persero) Padang Office with a total population of 131,233 participants, consisting of active civil servants and retired civil servants. The sample in this study consisted of 100 respondents determined by Slovin formula. The data of this study were collected through questionnaires with Likert scale measurements. The data of this study were analyzed by the Simple Regression test. The results of this study proved that there is a complaint management variable on the satisfaction of participants/customers at PT. Taspen (Persero) Padang Office.

Keywords : Complaint Management, Participant, Customer Satisfaction

Corresponding author. Email.tessaazhari93@gmail.com,alfrinaldi@gmail.com

How to cite this article. Azhari. T \& Frinaldi. A. (2019). Pengaruh Pengelolaan Pengaduan terhadap Kepuasan Peserta di PT. Taspen (Persero) Kantor Cabang Padang. Jurnal Mahasiwa Ilmu Administrasi Publik (JMIAP) Jurusan Ilmu Administrasi Negara Fakultas Ilmu Sosial Universitas Negeri Padang, Volume 1 (3), Hal. 76-84

http://jmiap.ppj.unp.ac.id

ISSN : 2684-818X (Online), ISSN : 2338-7378 (Print)

Copyright $(2019$. Published by Pusat Kajian-Pemberdayaan dan Pelayanan Masyarakat (PK-P2M) FIS UNP Padang
\end{abstract}


Tessa Azhari, Aldri Frinaldil Pengaruh Pengelolaan Pengaduan terhadap Kepuasan Peserta di PT. Taspen (Persero) Kantor Cabang Padang

\section{PENDAHULUAN}

Berdasarkan Peraturan Presiden No. 76 Tahun 2013 mengenai "Pengelolaan Pengaduan Pelayanan Publik" menjelaskan bahwa pengelolaan pengaduan adalah kegiatan penanganan pengaduan sesuai dengan mekanisme dan tata cara pengelolaan pengaduan (Indonesia, n.d.). Sedangkan pengertian Pengaduan adalah penyampaian keluhan yang disampaikan pengadu kepada pengelola pengaduan pelayanan publik atas pelayanan pelaksana yang tidak sesuai dengan standar pelayanan, atau pengabaian kewajiban dan/atau pelanggaran penyelenggaraan oleh penyelenggara.

Begitu pula dengan PT. Taspen (Persero) sebagai Badan Usaha Milik Negara (BUMN), dengan menjalankan tugas pemerintah, yakni dalam menyelenggarakan Program Asuransi Sosial Pegawai Negeri Sipil yang terdiri dari Tabungan Hari Tua (THT), Jaminan Kematian (JKM) dan Jaminan Kecelakaan Kerja (JKK). Hal tersebut sesuai dengan Peraturan Pemerintah Nomor: 25 dan 26 Tahun 1981 yang bertujuan meningkatkan kesejahteraan Pegawai Negeri pada saat memasuki masa purna bakti atau pension (Indonesia, 1981a, 1981b).

Berdasarkan hasil wawancara penulis dengan seorang Peserta Taspen, penulis menemukan bahwa kesalahan data yang diperoleh maupun yang dikelola oleh PT. Taspen (Persero) Kantor Cabang Padang dapat menimbulkan pengaduan atau keluhan(komplain) dari PNS dan Pensiunan selaku pelanggan atau peserta. Mulai dari kesalahan pada pencetakan dan pengelolaan smart card peserta Taspen, timbulnya Hutang gaji Terlanjur Bayar pada peserta yang mengharuskan peserta untuk melapor dan membayar hutang gaji yang terlanjur dan lain sebagainya.

Salah satu penyebabnya antara lain seperti data yang diinput sering keliru karena koordinasi dan komunkasi antara PT. Taspen dengan Satuan Kerja masih dinilai kurang. Keluhan atau permasalahan yang mereka alami mengharuskan peserta Taspen untuk melaporkan ke kantor Taspen yang berlokasi jalan Jend. Soedirman, Kota Padang, sedangkan peserta yang berdomisili di luar Kota Padang contohnya seperti Kepulauan Mentawai, Kabupaten Solok Selatan dan lain sebagainya. Jarak yang cukup jauh dan memakan waktu terkadang menjadi kendala bagi peserta Taspen untuk melaporkan perubahan data dan menyampaikan keluhannya.

Permasalahan Pengelolaan Pengaduan dapat dilihat dari lingkungan kerja di PT. Taspen Kantor Cabang Padang. Temuan penulis terdapat tumpukan kertas pengaduan untuk perbaikan smartcard, berupa fotocopyan kartu yang salah serta penulisan data yang benar, tumpukan kertas itu dibiarkan selama berhari-hari karena karyawan lebih mengutamakan tuntutan pekerjaan yang lain. Jadi pengaduan perbaikan smartcard seakan tidak diabaikan dan tidak dijadikan prioritas. Hal tersebut membuat peserta Taspen harus menunggu lebih lama perbaikan smartcard mereka tanpa pemberitahuan rentan waktu yang tidak jelas, sehingga peserta Taspen hanya menunggu dan pasif dalam mendapatkan layanan. peserta Taspen tidak mengetahui alur pengelolaan pengaduan atau keluhan yang seharusnya, karena kurangnya sosialisasi atau informasi terkait hal tersebut. Sehingga peserta Taspen yang ingin melaporkan pengaduannya lebih memilih menghubungi karyawan Taspen terkait melalui telepon ataupun kunjungan langsung ke PT. Taspen (Persero) Kantor Cabang Padang. Hal ini sesuai dengan pendapat N (57) seorang Pegawai Negeri Sipil (PNS) di salah satu instansi pemerintah di provinsi Sumatera Barat.

Berdasarkan fenomena diatas penulis tertarik untuk meneliti tentang "Pengaruh Pengelolaan Pengaduan Terhadap Kepuasan Peserta di PT. Taspen (Persero) Kantor Cabang Padang". Dengan rumusan masalah Apakah terdapat pengaruh 
Tessa Azhari, Aldri Frinaldil Pengaruh Pengelolaan Pengaduan terhadap Kepuasan Peserta di PT. Taspen (Persero) Kantor Cabang Padang

pengelolaan pengaduan terhadap kepuasan peserta PT. Taspen (Persero) Kantor Cabang Padang?

\section{TINJAUAN PUSTAKA}

\section{Konsep Pengelolaan Pengaduan}

Menurut pendapat Fornell dan Westbrook mengemukan pengelolaan pengaduan sebagai: "Complaint management is the process of dissemination of information aimed at identifying and correcting various causes of customer dissatisfaction". Pengelolaan pengaduan adalah proses penyebaran informasi yang bertujuan mengidentifikasi dan memperbaiki berbagai penyebab ketidakpuasan pelanggan. Selanjutnya berdasarkan pendapat. (Filip, 2013: 272).

Jadi berdasarkan defenisi di atas, penulis menyimpulkan bahwa Pengelolaan pengaduan merupakan serangkaian proses yang meliputi tahapan mulai dari laporan pengaduan yang masuk, penanganan keluhan dampai dengan proses penyelesaian pengaduan/keluhan dengan tujuan membangun kembali kepuasan dan kepercayaan dari pelanggan. Hariani menjelaskan bahwa dalam sistem pengelolaan terdapat prinsip-prinsip berikut ini:

1) Kemudahan;

2) Tanggap; Rentang waktu;

3) Terdokumentasi;

4) Kejelasan;

5) Kerahasiaan;

6) Hak dan kewajiban (akuntabilitas);

7) Transparansi Komitmen Keadilan bagi semua pihak. (Mursalim, 2018: 7)

Tjiptono mengemukakan komponen utama dari manajemen pengaduan yang penulis adopsi dan adaptasi sebagai indikator dari pengelolaan pengaduan, antara lain sebagai berikut:

1) Komitmen: seluruh anggota organisasi berkomitmen untuk mendengarkan dan menyelesaikan masalah komplain demi meningkatkan kualitas produk dan jasa.
2) Visible: Manajemen dengan jelas menginformasikan kepada pelanggan dan karyawan mengenai cara penyampaian komplain dan pihakpihak yang dapat dihubungi.

3) Fairness: komplain mendapatkan perlakuan sama.

4) Kesederhanaan: Prosedur komplain sederhana dan mudah dipahami pelanggan (masyarakat).

5) Accessible: organisasi menjamin bahwa pelanggan secara mudah, bebas, dan murah dapat menyampaikan complain.

6) Kecepatan: komplain ditangani dengan cepat melalui rentang waktu penyelesaian yang realistis serta diinformasikan kepada pelanggan.

7) Remedy: Pemecahan dan penyelesaian yang tepat untuk setiap komplain ditetapkan dan diimplementasikan secara konsekuen.

8) Confidential: Keinginan pelanggan akan privasi dan kerahasiaan dihargai dan dijaga.

9) Records: Datai komplain disusun sedemikian rupa sehingga memudahkan upaya perbaikan berkesinambungan.

10) Sumber daya: Perusahaan mengalokasikan sumber daya, sarana dan prasarana yang memadai.(Mursalim, 2018: 5)

\section{Kepuasan Peserta/Pelanggan}

Konsep kepuasan pelanggan digunakan dalam penelitian ini sebagai dasar pemikiran teoritik untuk memahami konsep dan indikator pengukuran kepuasan peserta PT. Taspen (Persero) Kantor Cabang Padang. Kepuasan pelanggan adalah perbandingan antara persepsi pelanggan terhadap jasa yang diterima dan harapannya sebelum menggunakan produk (Zeithaml, Bitner dalam H, Kumadji, \& Yulianto, 2014: 3). Kotler dalam (Nasution, 2004: 104) mendefinisikan kepuasan pelanggan adalah perasaan seseorang setelah membandingkan antara kinerja yang ia rasakan/alami terhadap harapannya. 
Tessa Azhari, Aldri Frinaldil Pengaruh Pengelolaan Pengaduan terhadap Kepuasan Peserta di PT. Taspen (Persero) Kantor Cabang Padang

Berdasarkan pendapat (Frinaldi \& Embi, 2015: 106) menjelaskan bahwa aspek kepuasan publik atau masayarakat dapat dinilai dari perasaan seperti kebahagiaan, kesenangan, dan sayang saat merasa puas dengan produk/jasa yang pelanggan terima. Sebaliknya, mereka akan terlihat cemberut, kecewa, kesal, dan bersumpah atau bertindak cara tidak puas atas produk/jasa yang pelanggan terima. Berdasarkan beberapa hal di atas, pendapat tentang kepuasan pelanggan maka dapat disimpulkan bahwa kepuasan pelanggan adalah perasaan seseorang pelanggan setelah menyamakan sesuatu yang diterima dengan yang pelanggan harapkan. Menurut Gibson, dkk menjelaskan bahwa kepuasan pada dasarnya berhubungan dengan aspek dari kebutuhan pelanggan, jika kebutuhan pelanggan terpenuhi maka pelanggan tersebut akan merasa puas, begitu pula sebaliknya (Kasandra \& aldri, 2018: 42).

Selanjutnya Tjiptono mengemukakan bahwa kepuasan pelanggan juga memiliki potensi memberikan beberapa manfaat yang spesifik, diantaranya sebagai berikut ini:

a) Memiliki dampak yang positif terhadap loyalitas pelanggan.

b) Sanggup menjadi sumber pendapatan masa yang akan datang, seperti melalui pembelian ulang, cross-selling, dan up-selling.

c) Mengurangi biaya transaksi pelanggan di masa yang akan datang, seperti biaya-biaya komunikasi pemasaran, penjualan, dan layanan pelanggan.

d) Menekan volatilitas dan risiko berkenaan dengan prediksi aliran kas di masa yang akan datang.

e) Menaikkan pemanfaatan harga, seperti kemauan pelanggan untuk membayar harga premium dan pelanggan cenderung tidak beralih ke lain perusahaan.

f) Menumbuhkan rekomedasi dan menularkan pengaruh posiitif.

g) Pelanggan cenderung lebih reseptif terhadap product-line extensions, brand extensions, dan new add-on service yang dianjurkan perusahaan.

h) Menaikkan bargaining power relatif perusahaan terhadap jaringan penyedia, mitra bisnis, dan saluran distribusi.(Tjiptono, 2008: 169)

Menurut Hawkins dan Lonney dalam (Tjiptono, 2014: 101) indikator pembentuk kepuasan konsumen terdiri dari :

a) Kesediaan merekomendasi: kesediaan konsumen untuk merekomendasikan jasa yang telah dirasakan kepada teman atau keluarga.

b) Kesesuaian harapan: tingkat kesesuaian antara kinerja jasa yang diharapkan oleh konsumen dengan yang dirasakan oleh konsumen.

c) Minat berkunjung kembali: kesediaan konsumen untuk berkunjung kembali atau melakukan pemakaian ulang terhadap jasa terkait

\section{METODE PENELITIAN}

Penelitian ini menggunakan pendekatan kuantitatif. Penelitian telah dilakukan di PT. Taspen (Persero) Kantor Cabang Padang dengan waktu penelitian selama kurang lebih 3 bulan. Populasi penelitian ini sebanyak 131.233 responden, yang terdiri dari PNS aktif dan pensiunan PNS. Sedangkan untuk sampel yang digunakan dalam penelitian ini sebanyak 100 responden yang dihitung menggunakan rumus Slovin. Untuk pengambilan sampel menggunakan teknik Simple Random Sampling dikarenakan pengambilan anggota sampel dari populasi yang dilakukan secara acak tanpa memperhatikan strata yang ada dalam populasi itu (Sugiyono, 2016: 93). Pengumpulan data penelitian ini dilakukan dengan melakukan penyebaran kuesioner dengan pengukuran skala Likert. Teknik analisis data dalam penelitian ini menggunakan uji regresi sederhana. 
Tessa Azhari, Aldri Frinaldi I Pengaruh Pengelolaan Pengaduan terhadap Kepuasan Peserta di PT. Taspen (Persero) Kantor Cabang Padang

HASIL DAN PEMBAHASAN

\section{Deskripsi Responden}

Pada penelitian ini responden berjumlah 100 orang peserta/pelanggan PT. Taspen
(Persero) Kantor Cabang Padang, berikut karakteristik responden dalam penelitian ini disajikan pada tabel di bawah ini:

Tabel 1. Karakteristik Responden

\begin{tabular}{|c|c|c|}
\hline Karakteristik & Frekuaensi & Persentase \\
\hline \multicolumn{3}{|l|}{ Jenis Kelamin } \\
\hline laki-laki & 29 & $29 \%$ \\
\hline perempuan & 71 & $71 \%$ \\
\hline \multicolumn{3}{|l|}{ Usia } \\
\hline $24-35$ & 4 & $4 . \%$ \\
\hline $36-45$ & 5 & $5 \%$ \\
\hline $46-55$ & 17 & $17 \%$ \\
\hline $56-65$ & 48 & 48.0 \\
\hline $66-75$ & 21 & $21 \%$ \\
\hline$>75$ & 5 & $5 \%$ \\
\hline \multicolumn{3}{|c|}{ Pendidikan Terakhir } \\
\hline SD & 1 & $1 \%$ \\
\hline SMP & 3 & $3 \%$ \\
\hline SMA & 41 & $41 \%$ \\
\hline DIPLOMA & 16 & $16 \%$ \\
\hline $\mathrm{S} 1$ & 37 & $37 \%$ \\
\hline S2 & 2 & $2 . \%$ \\
\hline \multicolumn{3}{|l|}{ Status Peserta } \\
\hline PNS Aktif & 37 & $37 \%$ \\
\hline Pensiunan PNS & 63 & $63 \%$ \\
\hline
\end{tabular}

Sumber: Hasil Olahan Data Penelitian 2019

Dari tabel di atas dapat diketahui bahwa dari 100 responden, peserta/pelanggan PT. Taspen (Persero) Kantor Cabang Padang didominasi oleh peserta dengan jenis kelamin perempuan sebanyak 71 orang dengan persentase $71 \%$. penulis mendapati Usia responden yang paling dominan berkisar dari 56-65 tahun sebanyak 48 orang dengan hasil persentase $48 \%$, dan peserta dengan pendidikan terakhir yang paling dominan adalah SMA sebanyak 41 orang dengan perhitungan persentase $41 \%$ dengan memiliki status kepesertaan sebagai pensiunan PNS sebanyak 63 orang dengan perhitungan persentase $63 \%$.

\section{Deskripsi Variabel Pengelolaan Pengaduan}

Berikut penjelasan Secara umum hasil penelitian yang menunjukkan nilai rata-rata TCR variabel pengelolaan pengaduan yang dapat dilihat pada tabel 2 di bawah ini: 
Tessa Azhari, Aldri Frinaldil Pengaruh Pengelolaan Pengaduan terhadap Kepuasan Peserta di PT. Taspen (Persero) Kantor Cabang Padang

Tabel 2. Deskripsi Variabel Pengelolaan Pengaduan

\begin{tabular}{|l|c|c|c|c|c|c|c|}
\hline \multirow{2}{*}{ Item Pernyataan } & \multirow{2}{*}{$\mathrm{N}$} & \multirow{2}{*}{ Mean } & \multirow{2}{*}{$\mathrm{TCR}$} & \multicolumn{4}{c|}{ Kategori Mean Responden } \\
\cline { 5 - 8 } & & & & Tinggi & $\%$ & Rendah & $\%$ \\
\hline Komitmen & 100 & 3.27 & $81.75 \%$ & 34 & $34 \%$ & 66 & $66 \%$ \\
\hline Visible & 100 & 3.05 & $76.25 \%$ & 32 & $32 \%$ & 68 & $68 \%$ \\
\hline Fairness & 100 & 3.07 & $76.75 \%$ & 31 & $31 \%$ & 69 & $69 \%$ \\
\hline Kesederhanaan & 100 & 3.32 & $83 \%$ & 42 & $42 \%$ & 58 & $58 \%$ \\
\hline Accessible & 100 & 3.05 & $76.25 \%$ & 26 & $26 \%$ & 74 & $74 \%$ \\
\hline Kecepatan & 100 & 3.2 & $80 \%$ & 39 & $39 \%$ & 61 & $61 \%$ \\
\hline Remedy & 100 & 3.39 & $84.75 \%$ & 43 & $43 \%$ & 57 & $57 \%$ \\
\hline Confidential & 100 & 3.36 & $84 \%$ & 46 & $46 \%$ & 54 & $54 \%$ \\
\hline Records & 100 & 2.7 & $67.5 \%$ & 61 & $61 \%$ & 39 & $39 \%$ \\
\hline Sumber daya & 100 & 2.67 & $66.75 \%$ & 62 & $62 \%$ & 38 & $38 \%$ \\
\hline $\begin{array}{l}\text { Rata-rata } \\
\text { Pengelolaan Pengaduan }\end{array}$ & 100 & 3.11 & 77.7 & 41 & $41 \%$ & 59 & $59 \%$ \\
\hline
\end{tabular}

Sumber: Hasil Olahan Data Penelitian 2019

Berdasarkani Tabel 2 di atas maka menghasilkan rata-rata pengelolaan pengaduani di Taspen berada dikategori tinggi $(77,7 \%)$. Jika dilihat secara rinci, dapat dijelaskan bahwa aspek komitmen karyawan Taspen berada pada kategori sangat tinggi $(81.75 \%)$. pada aspek visible berada pada kategori tinggi(76.25\%). Aspek Fairness juga pada kategori tinggi (76.75\%), Kemudian aspek Kesederhanaan berada pada kategori sangat tinggi (83\%). Aspek Accessible berada pada kategori tinggi tinggi (76.25\%), pada aspek Kecepatan berada pada kateori tinggi (80\%), pada aspek Remedy berada pada kategorisangat tinggi $(84.75 \%)$, pada aspek Confidential berada pada kategori sangat tinggi (84\%). Pada aspek Records berada pada kategori tinggi (67.5\%), dan Pada aspek Sumber daya berada pada kategori tinggi $(66.75 \%)$, . Selanjutnya jika dilihat dari kategori mean responden pengelolaan pengaduan yang berada dibawah rata-rata (mean) lebih besar persentasenya di bandingkan dengan pengelolaan pengaduaan yang berada di atas rata-rata (mean) dengan perbandingan 41\%: 59\%. Sehingga dapat disimpulkan bahwa pengelolaan Pengaduan di PT. Taspen (Persero) Kantor Cabang Padang berada pada kategori sedang/cukup.

\section{Deskripsi Variabel Kepuasan Peserta}

Berikut penjelasan Secara umum hasil penelitian yang menunjukkan nilai rata-rata TCR variabel kepuasan peserta yang dapat dilihat pada tabel 3 di bawah ini:

Tabel 3. Deskripsi Variabel Kepuasan Peserta/Pelanggan

\begin{tabular}{|l|c|c|c|c|c|c|c|}
\hline \multicolumn{1}{|c|}{ Item Pernyataan } & $\mathrm{N}$ & Mean & $\mathrm{TCR}$ & \multicolumn{3}{|c|}{ Kategori Mean Responden } \\
\cline { 5 - 8 } & & & & Tinggi & $\%$ & Rendah & $\%$ \\
\hline Kesesuaian harapan & 100 & 3.22 & $\begin{array}{c}80.50 \\
\%\end{array}$ & 36 & $36 \%$ & 64 & $64 \%$ \\
\hline Minat berkunjung kembali & 100 & 2.93 & $\begin{array}{c}73.25 \\
\%\end{array}$ & 69 & $69 \%$ & 31 & $31 \%$ \\
\hline Kesediaan merekomendasi & 100 & 2.28 & $57 \%$ & 40 & $40 \%$ & 60 & $60 \%$ \\
\hline Rata-rata Variabel Kepuasan & 100 & 2.81 & $\begin{array}{c}70.25 \\
\%\end{array}$ & 55 & $55 \%$ & 45 & $45 \%$ \\
\hline
\end{tabular}

Sumber: Hasil Olahan Data Penelitian 2019

Berdasarkani Tabel 3 di atas maka menghasilkan rata-rata Kepuasan Peserta/Pelanggan di Taspen berada dikategori tinggi (70,25\%). Jika dijelaskan lebih rinci, dapat dijelaskan bahwa aspek kesesuaian harapan juga berada pada kategori tinggi $(80.50 \%)$, pada aspek minat berkunjung kembali juga berada pada 
Tessa Azhari, Aldri Frinaldil Pengaruh Pengelolaan Pengaduan terhadap Kepuasan Peserta di PT. Taspen (Persero) Kantor Cabang Padang

kategori tinggi $(73,25 \%)$, dan pada aspek kesedian merekomendasi berada pada kategori sedang (57\%). Selanjutnya jika dilihat dari kategori mean responden kepuasan peserta/rapelanggan yang berada dibawah rata-ta (mean) lebih kecil persentasenya di bandingkan dengan kepuasan peserta/pelanggan yang berada di atas rata-rata (mean) dengan perbandingan 55\% : 45\%. Sehingga dapat disimpulkan bahwa pengelolaan Pengaduan di PT.
Taspen (Persero) Kantor Cabang Padang berada pada kategori sedang/cukup.

Selanjutnya dilakukan uji regresi sederhana untuk melihat apakah terdapat pengaruh pengelolaan pengaduan terhadap kepuasan peserta/pelanggan di PT. Taspen (Persero) Kantor Cabang Padang. Hasil uji tersebut dapat dilihat pada tabel 3 di bawah ini:

\section{Tabel 4. Pengaruh Variabel Pengelolaan Pengaduan (Secara Simultan) terhadap Kepuasan Peserta/Pelanggan}

Model Summary ${ }^{\mathrm{b}}$

\begin{tabular}{|l|r|r|r|r|r|}
\hline Model & \multicolumn{1}{|c|}{$\mathrm{R}$} & R Square & \multicolumn{1}{c|}{$\begin{array}{c}\text { Adjusted R } \\
\text { Square }\end{array}$} & $\begin{array}{c}\text { Std. Error of the } \\
\text { Estimate }\end{array}$ & Durbin-Watson \\
\hline 1 & $.325^{\mathrm{a}}$ & .106 & .096 & .46218 & 1.889 \\
\hline
\end{tabular}

a. Predictors: (Constant), RATA-RATA PENGADUAN

b. Dependent Variable: RATA-RATA KEPUASAAN

Sumber: Hasil Olahan Data Penelitian 2019

Berdasarkan Tabel 4 di atas maka dapat dijelaskan bahwa Adjusted R Square dari hasil analisis uji regresi adalah 0,096. Dengan demikian bisa disimpulkan bahwa besarnya pengaruh pengelolaan pengaduan terhadap kepuasan peserta/pelanggan taspen sebesar 9,6\%. Selebihnya sebesar $90,4 \%$ dipengaruhi oleh variabel lain di luar peneltian ini.

Penelitian ini memperoleh hasil yang dapat disimpulkan bahwa penelitian ini ikut memperkuat dan mendukung teori yang telah ada. Seperti teori yang dikemukakan Fornell dan Westbrook mengemukan pengelolaan pengaduan sebagai Pengelolaan proses penyebaran informasi yang bertujuan mengidentifikasi dan memperbaiki berbagai penyebab ketidakpuasan pelanggan. Defenisi pengelolaan pengaduan tersebut menunjukkan bahwa informasi yang didapatkan pada pengaduan atau keluhan yang disampaikan memiliki tujuan unuk menetapkan penyebab ketidakpuasan pelanggan dan mencari solusi perbaikan.
Penelitian ini juga memperkuat hasil penelitian yang dilakukan oleh beberapa peneliti lainnya diantaranya, Menurut (Filip, 2013) dengan judul Complaint Manajement: A Customer Satisfaction Learning Process (Pengelolaan/manajemen Pengaduan: Sebuah Proses Pembelajaran Kepuasan Pelanggan). Dalam penelitian ini menjelaskan bahwa manajemen pengaduan/keluhan harus menjadi indikator penilaian kinerja organisasi, karena dari proses manajemen pengaduan yang efektif dapat mempermudah perusahaan untuk mendiagnosis dan mempelajari kelemahan perusahaan. Selain itu, penelitian ini juga menyarankan perusahaan untuk menstimulus/mendorong pelanggan untuk mengungkapkan keluhan dan ketidak puasan yang dialaminya, agar pelanggan dapat memberikan umpan balik sehingga ketidak puasan dan permasalahan yang dihadapi pelanggan dapat diselesaikan dan dicarikan solusinya. Sehingga dapat meningkatkan kepuasan pelanggan.

Kemudian penelitian yang dilakukan oleh Berliantina Rosita dan Sigit 
Tessa Azhari, Aldri Frinaldil Pengaruh Pengelolaan Pengaduan terhadap Kepuasan Peserta di PT. Taspen (Persero) Kantor Cabang Padang

Indrawijaya (2015) dengan judul Pengaruh Penanganan Komplain Terhadap Kepuasan Nasabah. Penelitian ini mengemukakan bahwa didapat pengaruh yang nyata penanganan komplain terhadap kepuasan pelanggan.

\section{PENUTUP}

Berdasarkan analisis data yang telah dilakukan maka dapat disimpulkan bahwa: variabel pengelolaan pengaduan berada pada kategori sedang atau cukup sedangkan untuk variabel kepuasan peserta/pelanggan juga berada pada kategori sedang. Sedangkan untuk pengaruh pengelolaan pengaduan terhadap kepuasan peserta/pelanggan di PT. Taspen (Persero) Kantor Cabang Padang menunjukkan bahwa terdapat pengaruh yang signifikan. Pengelolaan pengaduan berpengaruh secara signifikan terhadap kepuasan peserta. Variabel pengelolaan pengaduan berpengaruh secara signifikan terhadap kepuasan peserta karena signifikansi 0,001 dengan kata lain penelitian ini terbukti dopat dipercaya sebesar 99,9\%. Pengelolaan pengaduan berkontribusi terhadap kepuasan sebesar 9,6\% sedangkan sisanya $90,4 \%$ berkontribusi oleh variabel lain yang tidak diteliti dalam penelitian ini. Sehingga dapat dikatakan semakin besar kekuatan pengelolaan pengaduan maka semakin besar juga kepuasan peserta di PT. Taspen (Persero) Kantor Cabang Padang. Sementara kepuasan peserta yang ada baru berkategori sedang sebanyak 55\% saja.

Peneliti masih menyadari bahwa hasil penelitian ini masih mengandung sesuatu yang belum diteliti dalam penelitian ini, untuk itu peneliti selanjutnya diharapkan mampu menyempurnakan penelitian ini. Peneliti menyadari bahwa hasil penelitian ini masih memiliki kelemahan tertentu, maka dari itu diharapkan kepada peneliti selanjutnya untuk lebih menyempurnakan penelitian ini.

\section{DAFTAR KEPUSTAKAAN}

Filip, A. (2013). Complaint management:
A customer satisfaction learning process. Procedia - Social and Behavioral Sciences, 93, 271-275. https://doi.org/10.1016/j.sbspro.2013. 09.188

Frinaldi, A., \& Embi, M. A. (2015). Influence of Public Service Quality in Citizen Satisfaction (Study in Private Hospital Y in Padang, West Sumatra Province), 6(1), 102-114.

H, M. E., Kumadji, S., \& Yulianto, E. (2014). Pengaruh Kualitas Pelayanan Terhadap Kepuasan, Kepercayaan Dan Loyalitas ( Survei pada Pelanggan yang Menginap di Jambuluwuk Batu Resort Kota Batu ), 15(2), 1-9.

Hadi, S. (2004). Metodologi Research. Yogyakarta: Andi Offset.

Indonesia, R. (n.d.). Peraturan Presiden No. 76 Tahun 2013 Tentang Pengelolaan Pengaduan Pelayanan Publik.

Indonesia, R. (1981a). Peraturan Pemerintah Republik Indonesia Nomor 25 Tahun 1981 Tentang Asuransi Sosial Pegawai Negeri Sipil.

Indonesia, R. (1981b). Peraturan Pemerintah Republik Indonesia Nomor 26 Tahun 1981 Tentang Pengalihan Bentuk Perusahaan Umum Dana Tabungan Dan Asuransi Pegawai Negeri Menjadi Perusahaan Perseroan (Persero), 1-7.

Mursalim, S. W. (2018). Analisis Manajemen Pengaduan Sistem Layanan Aspirasi Pengaduan Online Rakyat (LAPOR) Di Kota Bandung, $X V(1), 1-17$.

Nasution, N. (2004). Manajemen Jasa Terpadu:Total Service Manajement. Jakarta: Ghalia Indonesia.

Sugiyono. (2016). Metodologi Penelitian Administrasi. Bandung: Alfabeta.

Tjiptono, F. (2008). Service Manajemen: Mewujudkan Layanan Prima. 
Tessa Azhari, Aldri Frinaldi I Pengaruh Pengelolaan Pengaduan terhadap Kepuasan Peserta di PT. Taspen (Persero) Kantor Cabang Padang

Yogyakarta: Andi Offset.

Tjiptono, F. (2014). PemasaranJasa -

Prinsip, Penerapan,dan Penelitian.

Yogyakarta: Andi Offset. 